\title{
Impact of Pomegranate Peels and Moringa oleifera Extract on the Viability of E.coli O111:H2 (EHEC 0111:H2) in Yoghurt
}

\author{
Elbagory AM ${ }^{1 *}$, Heba Hussien², Seham N Homouda ${ }^{3}$ and Eman K Fathalla ${ }^{3}$ \\ ${ }^{1}$ Food Hygiene and Control Department, Faculty of Veterinary Medicine, Menoufia University, Egypt \\ ${ }^{2}$ Food Hygiene and Control Department, Faculty of Veterinary Medicine, University of Sadat City, Egypt \\ ${ }^{3}$ Animal Health Research Institute, Tanta, Egypt
}

*Corresponding author: Elbagory AM, Food Hygiene and Control Department, Faculty of Veterinary Medicine, Menoufia University, Egypt, Email: elbagory200@yahoo.com

Received: 12 Jan, 2019 | Accepted: 01 Apr, 2019 | Published: 07 Apr, 2019

Citation: Elbagory AM, Hussien H, Homouda SN, Fathalla EK (2019) Impact of Pomegranate Peels and Moringa oleifera Extract on the Viability of E.coli O111:H2 (EHEC O111:H2) in Yoghurt. Nutr Food Technol Open Access 5(1): dx.doi.org/10.16966/2470-6086.154

Copyright: (c) 2019 Elbagory AM, et al. This is an open-access article distributed under the terms of the Creative Commons Attribution License, which permits unrestricted use, distribution, and reproduction in any medium, provided the original author and source are credited.

\begin{abstract}
Pomegranate is a functional food of great interest and it has a multiple beneficial effects on human health. Moringa oleifera leaves have a high content of essential amino acids, iron protein and Vitamin B complex so the pomegranate and Moringa oleifera were used to improve the nutritional and hygienic quality of food products by using their extracts. Different ratio ( $1 \%$ and $2 \%)$ from ethanolic extract of pomegranate peels and from ethanolic extract of Moringa oleifera leaves were used in production of yoghurt and stored at $4 \pm 1^{\circ} \mathrm{C}$ for 14 days then were analyzed for sensory evaluation and other groups of yoghurt with the same treatments were evaluated for the viability of EHEC O111:H2 count experimentally. The results showed that the sensory analysis of all treatments and control yoghurt were acceptable for all judgment members either fresh or during storage. The concentration $2 \%$ of both pomegranate peels and Moringa oleifera leaves had the highest inhibitory effect against the tested bacteria population $(p<0.05)$ during the storage periods. It was concluded that the ethanolic extracts of both pomegranate peels and Moringa oleifera leaves can be used for yoghurt preservation to improve its quality.
\end{abstract}

Keywords: Moringa oleifera; Pomegranate peels; Yoghurt; EHEC (O111:H2)

\section{Introduction}

Recently, new trends in food processing to use the natural bioactive substances as antioxidants and antimicrobials to support dairy products for improving their hygienic quality and to safeguard human health. Plants are the cheapest and safer alternative sources of antimicrobials which may be added to food [1].

There are various natural antioxidants, antimicrobials, sweeteners and coloring agents that are derived from animals, plants and microorganisms. Bacteriocins, natamycin, reuterin from microbial sources; lysozyme, lactoperoxidase, lactoferrin from animal sources; polyphenols and essential oils from plant sources can be named as examples of natural preservatives [2].

Pomegranate (Punica granatum Linn.) is a potential medicinal plant of family punicaceae [3]. Pomegranate juice was used as a healthful beverage since it is a natural rich source of polyphenols, flavonoid and other antioxidants. It could be considered as functional ingredients for its anti-radical activities and it is a good supplement for food and dietetics [4].

Polyphenols, mainly ellagitannins and ellagic acid, are an important class of compounds well represented in pomegranate. These molecules are particularly abundant in pomegranate peels and are responsible for the antioxidant, anti-mutagenic, anticancer, anti-inflammatory, and anti-diabetic and health promoting role of this fruit. They act as radical scavengers, both in preventing the degradation of food and in protecting human body towards Reactive Oxygen Species (ROS), whose role in the pathogenesis of human diseases is widely recognized [5].

Administration of yoghurt supplemented with pomegranate juice is acceptable as functional food alleviates the harmful effect of $\mathrm{CCl}_{4}$ induced liver injury and offers a pleasant and effective route in increasing the total phenolic compound and antioxidant intake in our daily diet [6].

Moringa oleifera is known as "the tree of life". It is native to India and Africa and considered one of the most useful trees in the world because every part of the tree can be used for food, medication and industrial purpose [7]. Moringa oleifera leaves possess high concentration of protein, vitamins, potassium, calcium and iron, in addition to their contents of essential amino acids at acceptable concentration [8].

Several Moringa oleifera leaves extracts are important agents against many species of pathogenic bacteria, such as Staphylococcus aureus, Psedomonus aeruginosa and Bacillus cereus [9], Moringa oleifera or its 
extracts had been used to improve the nutritional quality of yoghurt, cottage cheese [10] and bakery products with special reference to protein, fiber and minerals [11].

Yoghurt is a very popular fermented dairy product in Egypt. Its production and consumption is growing continuously due to its health benefits beside its high nutritive value; being nutritionally rich in protein, calcium, riboflavin, Vitamin B6 and B12 [12].

Yoghurt is one of the fermented dairy products obtained from lactic acid fermentation by two species of lactic acid bacteria that are, Streptococcus thermophilus and Lactobacillus delbrueckii subsp. bulgaricus. This fermentation leads to acidification and milk coagulation [13].

Yoghurt shelf life is based on the organoleptic, chemical and microbiological characters that will be decreased if there are any changes in these characters during storage [14]. So, application of natural preservation is useful for yoghurt industries to produce new variety of functional and high quality yoghurts [15].

The purpose of this study was to investigate the effect of ethanolic extracts powder of pomegranate peels and Moringa oleifera at concentration 1 and $2 \%$ from each extract and their inhibitory effect on $\operatorname{EHEC~(O111:H2).~}$

\section{Materials and Methods}

\section{Chemicals and reagents}

Plant materials: Pomegranate fruits were collected at November from the local markets in EL Gharbia province, Egypt. Fresh leaves of Moringa oleifera were collected from different nurseries in EL Gharbia province, Egypt during the summer season.

Solvent: Ethanol (HPLC grade) was obtained from Merck (Darmstadt, Germany).

Milk: Fresh full fat buffalo's milk was obtained from Faculty of Agriculture, Tanta University.

Bacterial strain: E.coli strain O111:H2 was isolated from a previous study on some dairy product and serologically identified in Animal Health Research Institute (AHRI), Egypt.

Media: Eosin Methylene blue agar (Oxoid, UK).

\section{Preparation of the ethanolic extract of pomegranate peel} [16]

Pomegranate fruits were collected at November from the local markets, EL Gharbia province, Egypt. Pomegranate outer peels were separated. Collected peels was rinsed with tap water, dried and ground separately in a blender. Fifty grams of blended peels or arils were placed in $250 \mathrm{ml}$ Erlenmeyer flasks, followed by adding $100 \mathrm{ml}$ of solvent $95 \%$ ethanol (HPLC ethanol grade) as a solvent to extract polar and non-polar part of phytochemicals from pomegranate peels. The flasks were then shaken at room temperature for $18 \mathrm{hrs}$ prior to filtration. The filtrates were concentrated under reduced pressure with a rotary evaporator at $40^{\circ} \mathrm{C}$ for evaporation of ethanol. These crude extracts were kept at $4^{\circ} \mathrm{C}$ until use.

Preparation of ethanolic extract of Moringa oleifera leaves [17]

Fresh leaves of Moringa oleifera were collected from different nurseries in EL Gharbia, Egypt during the summer season and dried in shade at room temperature $\left(27\right.$ to $30^{\circ} \mathrm{C}$ ) to constant weight (to calculate the $\%$ yield of the plant extract=dry weight of extract $(\mathrm{g}) /$ initial weight of plant sample $\times 100 \%$ ). leaves of the plant were powdered by mortar and pestle and further reduced to a fine powder using blender. Powdered sample were transferred to closed flasks. Each flask sample was extracted with 95\% ethanol (HPLC ethanol grade). Where each sample (50 g) was mixed with $500 \mathrm{ml}$ of $95 \%$ ethanol, kept for shaking at 120 gravity unit for half an hour and allowed to precipitate at room temperature for $72 \mathrm{hrs}$, then each extract was filtered by Whatman filter paper. The obtained filtrates were then concentrated in rotary evaporator at $40^{\circ} \mathrm{C}$ for evaporation of ethanol then these crude extracts were kept at $4^{\circ} \mathrm{C}$ until use in the next day.

\section{Preparation of E.coli inoculum [18]}

E.coli strain O111:H2 was isolated from a previous study on some dairy products and serologically identified in Animal Health Research Institute (AHRI), Egypt.

E.coli was sub-cultured from stock cultures in sterile bottles containing nutrient broth incubated over-night at $37^{\circ} \mathrm{C}$. Directly, prior to the experiment, fresh microbial cultures were adjusted to 0.5 McFarland to be equivalent to about $10^{6} \mathrm{CFU} / \mathrm{ml}$.

\section{Preparation of yoghurt $[19,20]$}

The buffaloes' milk was heated to $85^{\circ} \mathrm{C}$ for 15 min followed by cooling at $43^{\circ} \mathrm{C}$. The buffaloes' milk was divided into five portions. The first group is considered as control. The second, third using of ( $1 \%$ and $2 \%)$ pomegranate peel extracts. The fourth and fifth were (1\% and $2 \%)$ of Moringa oleifera leaves extract respectively, all groups infected with E.coli O111:H2 (EHEC) culture, and then inoculated with 2\% (v/v) starter culture and allowed to incubate at $43^{\circ} \mathrm{C}$ for $3 \mathrm{hrs}$ till complete coagulate. Experimental Yoghurt samples were stored at $4 \pm 1^{\circ} \mathrm{C}$. The samples are examined at zero, 3, 7, 10 and 14 days. E. coli was enumerated on its selective media Eosin Methylene Blue (EMB). The experiment is repeated 3 times independently.

\section{Statistical analysis}

The data were analyzed and the mean and Standard Error (SE) were calculated by one way ANOVA test according to Statistical Analysis System Users Guide SAS (2004) software and probability of $(p<0.05)$ [21].

\section{Sensory evaluation}

Ten trained panelists from the staff members of the Dairy Science Department used a quality rating score card for the evaluation of flavor (50 points) body and texture (40 points) and appearance (10 points) [22].

\section{Results (Tables and Figures)}

\section{Discussion and Conclusion}

Results in table 1 indicate that treatment with Moringa oleifera leaves extract $(2 \%)$ had lower score of appearance among other treatments and control yoghurt. On the other hand, all treatments had more than $60 \%(6 / 10)$ of total scores for the appearance at the end of storage and were accepted.

The treatments and control yoghurt gained high scores in flavor. On the other hand all scores decreased through the progress in storage periods. There were not obvious differences among all treatments during the early stages of storage but was obviously in the end of storage period. In addition, all treatments and control yoghurt had a lot of $60 \%(30 / 50)$ from the total scores of flavor at the end of storage period and were still acceptable for the judgments. 
Table 1: Organoleptical properties of yoghurt fortified with different ratios of pomegranate fruit peels extract and Moringa oleifera leaves extract.

\begin{tabular}{|c|c|c|c|c|c|c|}
\hline \multirow{2}{*}{ Item } & \multirow{2}{*}{ Treatment } & \multicolumn{5}{|c|}{ Storage period } \\
\hline & & Zero day & $3^{\text {rd }}$ day & $7^{\text {th }}$ day & $10^{\text {th }}$ day & $14^{\text {th }}$ day \\
\hline \multirow{5}{*}{ Appearance (10) } & Control +ve & $6.5 \pm 0.28$ & $9.1 \pm 0.23$ & $9.27 \pm 0.14$ & $8.77 \pm 0.29$ & $8.1 \pm 0.29$ \\
\hline & $A$ & $6.17 \pm 0.16$ & $7.8 \pm 0.15$ & $8 \pm 0.17$ & $8.23 \pm 0.23$ & $7.5 \pm 0.35$ \\
\hline & B & $5.3 \pm 0.15$ & $7.67 \pm 0.35$ & $7.73 \pm 0.18$ & $7.67 \pm 0.3$ & $7.3 \pm 0.24$ \\
\hline & C & $4.67 \pm 0.17$ & $6 \pm 0.12$ & $6.3 \pm 0.38$ & $6.43 \pm 0.34$ & $6.1 \pm 0.26$ \\
\hline & $\mathrm{D}$ & $4.47 \pm 0.29$ & $5.7 \pm 0.31$ & $6.1 \pm 0.4$ & $5.93 \pm 0.35$ & $5.97 \pm 0.48$ \\
\hline \multirow{5}{*}{ Flavor (50) } & Control +ve & $44.2 \pm 0.44$ & $47.5 \pm 0.29$ & $46.2 \pm 0.6$ & $45.7 \pm 0.5$ & $43.8 \pm 0.16$ \\
\hline & $A$ & $43 \pm 0.29$ & $45 \pm 0.57$ & $44.3 \pm 0.72$ & $44.5 \pm 0.8$ & $42.52 \pm 0.4$ \\
\hline & B & $42.5 \pm 0.49$ & $45.2 \pm 0.4$ & $45.5 \pm 0.76$ & $43.8 \pm 0.6$ & $42 \pm 0.57$ \\
\hline & $\mathrm{C}$ & $40.8 \pm 0.70$ & $41.2 \pm 1.1$ & $41.5 \pm 0.86$ & $40.7 \pm 0.72$ & $40.3 \pm 0.73$ \\
\hline & D & $40.6 \pm 1.3$ & $41 \pm 1$ & $41.2 \pm 0.4$ & $40 \pm 0.70$ & $40.2 \pm 0.44$ \\
\hline \multirow{5}{*}{$\begin{array}{l}\text { Body \& texture } \\
(40)\end{array}$} & Control +ve & $37 \pm 0.49$ & $38 \pm 0.29$ & $38 \pm 0.5$ & $36.5 \pm 0.29$ & $35 \pm 0.57$ \\
\hline & A & $36.6 \pm 0.44$ & $36.8 \pm 0.4$ & $38 \pm 0.57$ & $37.6 \pm 0.83$ & $36 \pm 0.99$ \\
\hline & $\mathrm{B}$ & $37 \pm 0.58$ & $37.3 \pm 0.4$ & $38.5 \pm 0.28$ & $38 \pm 0.57$ & $35.5 \pm 0.29$ \\
\hline & $\mathrm{C}$ & $36.5 \pm 0.57$ & $37 \pm 0.58$ & $37.7 \pm 0.6$ & $37.3 \pm 0.88$ & $35.6 \pm 0.33$ \\
\hline & $\mathrm{D}$ & $37 \pm 0.28$ & $37.5 \pm 0.28$ & $38 \pm 0.29$ & $37.8 \pm 0.4$ & $36 \pm 0.58$ \\
\hline
\end{tabular}

The values represent Mean \pm SE of three experiments.

$A=$ Inoculated with $E$. coli and pomegranate fruit peels extract $1 \%$

$\mathrm{B}=$ Inoculated with $E$. coli and pomegranate fruit peels extract $2 \%$

$\mathrm{C}=$ Inoculated with $E$. coli and Moringa oleifera leaves extract $1 \%$

$\mathrm{D}=$ Inoculated with $E$. coli and Moringa oleifera leaves extract $2 \%$

Table 2: Antimicrobial activity of pomegranate fruit peels extract and Moringa oleifera leaves extract on E.coli count inoculated in yoghurt during refrigerated storage.

\begin{tabular}{|c|c|c|c|c|c|}
\hline $\begin{array}{c}\text { Duration/ } \\
\text { Groups }\end{array}$ & Zero day & $3^{\text {rd }}$ day & $7^{\text {th }}$ day & $10^{\text {th }}$ day & $14^{\text {th }}$ day \\
\hline Control +ve & $2.87 \times 10^{6 a} \pm 0.15 \times 10^{6}$ & $2.33 \times 10^{6 a} \pm 0.12 \times 10^{6}$ & $2.07 \times 10^{6 a} \pm 0.22 \times 10^{6}$ & $6.60 \times 10^{5 \mathrm{a}} \pm 0.34 \times 10^{5}$ & $4.13 \times 10^{5 a} \pm 0.24 \times 10^{5}$ \\
\hline A & $2.50 \times 10^{6 a b} \pm 0.16 \times 10^{6}$ & $1.83 \times 10^{6 b} \pm 0.2 \times 10^{6}$ & $9.33 \times 10^{5 b} \pm 0.17 \times 10^{5}$ & $5.60 \times 10^{4 b} \pm 0.31 \times 10^{4}$ & $2.97 \times 10^{4 b} \pm 0.2 \times 10^{4}$ \\
\hline B & $2.10 \times 10^{6 b} \pm 0.21 \times 10^{6}$ & $6.37 \times 10^{5 c} \pm 0.41 \times 10^{5}$ & $5.80 \times 10^{5 c} \pm 0.21 \times 10^{5}$ & $3.47 \times 10^{4 \mathrm{bc}} \pm 0.29 \times 10^{4}$ & $1.83 \times 10^{4 b} \pm 0.08 \times 10^{4}$ \\
\hline C & $2.83 \times 10^{6 a} \pm 0.12 \times 10^{6}$ & $1.82 \times 10^{6 \mathrm{~b}} \pm 0.09 \times 10^{6}$ & $9.97 \times 10^{5 b} \pm 0.52 \times 10^{5}$ & $6.17 \times 10^{4 b} \pm 0.44 \times 10^{4}$ & $2.20 \times 10^{4 b} \pm 0.23 \times 10^{4}$ \\
\hline D & $2.53 \times 10^{6 a b} \pm 0.08 \times 10^{6}$ & $1.55 \times 10^{6 b} \pm 0.14 \times 10^{6}$ & $8.13 \times 10^{5 b c} \pm 0.24 \times 10^{5}$ & $1.77 \times 10^{3 c} \pm 0.43 \times 10^{3}$ & $2 \times 10^{2 b} \pm 0.28 \times 10^{2}$ \\
\hline
\end{tabular}

The values represent Mean \pm SE of three experiments. Means within a column followed by different letters are significant differences $(p<0.05)$

$A=$ Inoculated with $E$. coli and pomegranate fruit peels extract $1 \%$.

$\mathrm{B}=$ Inoculated with $E$. coli and pomegranate fruit peels extract $2 \%$.

$\mathrm{C}=$ Inoculated with $E$. coli and Moringa oleifera leaves extract $1 \%$.

$\mathrm{D}=$ Inoculated with $E$. coli and Moringa oleifera leaves extract $2 \%$.

Table 3: Reduction \% of E.coli counts artificially inoculated into yoghurt.

\begin{tabular}{|c|c|c|c|c|c|}
\hline Duration (hrs)/ Groups & Zero day & $3^{\text {rd day }}$ & $7^{\text {th }}$ day & $10^{\text {th }}$ day & $14^{\text {th }}$ day \\
\hline Control +ve & 00 & $18.80 \pm 3.5$ & $27.80 \pm 4.9$ & $77 \pm 9.5$ & $85 \pm 4.1$ \\
\hline A & $12.89 \pm 4.3$ & $36.23 \pm 7.1$ & $67.49 \pm 5.3$ & $98.04 \pm 2.3$ & $98.96 \pm 2.7$ \\
\hline B & $26.80 \pm 7.2$ & $77.80 \pm 6.3$ & $79.70 \pm 5.5$ & $98.80 \pm 3.1$ & $99.36 \pm 2.2$ \\
\hline C & $1.40 \pm 0.75$ & $36.58 \pm 5.7$ & $65.26 \pm 5$ & $97.85 \pm 2.1$ & $99.20 \pm 2.9$ \\
\hline D & $11.84 \pm 2.9$ & $46 \pm 7.5$ & $71.67 \pm 2.8$ & $99.93 \pm 3.8$ & $99.99 \pm 3.9$ \\
\hline
\end{tabular}

The values represent Mean \pm SE of three experiments

$A=$ Inoculated with $E$. coli and pomegranate fruit peels extract $1 \%$

$\mathrm{B}=$ Inoculated with $E$. coli and pomegranate fruit peels extract $2 \%$

$C=$ Inoculated with $E$. coli and Moringa oleifera leaves extract $1 \%$

$\mathrm{D}=$ Inoculated with $E$. coli and Moringa oleifera leaves extract $2 \%$ 


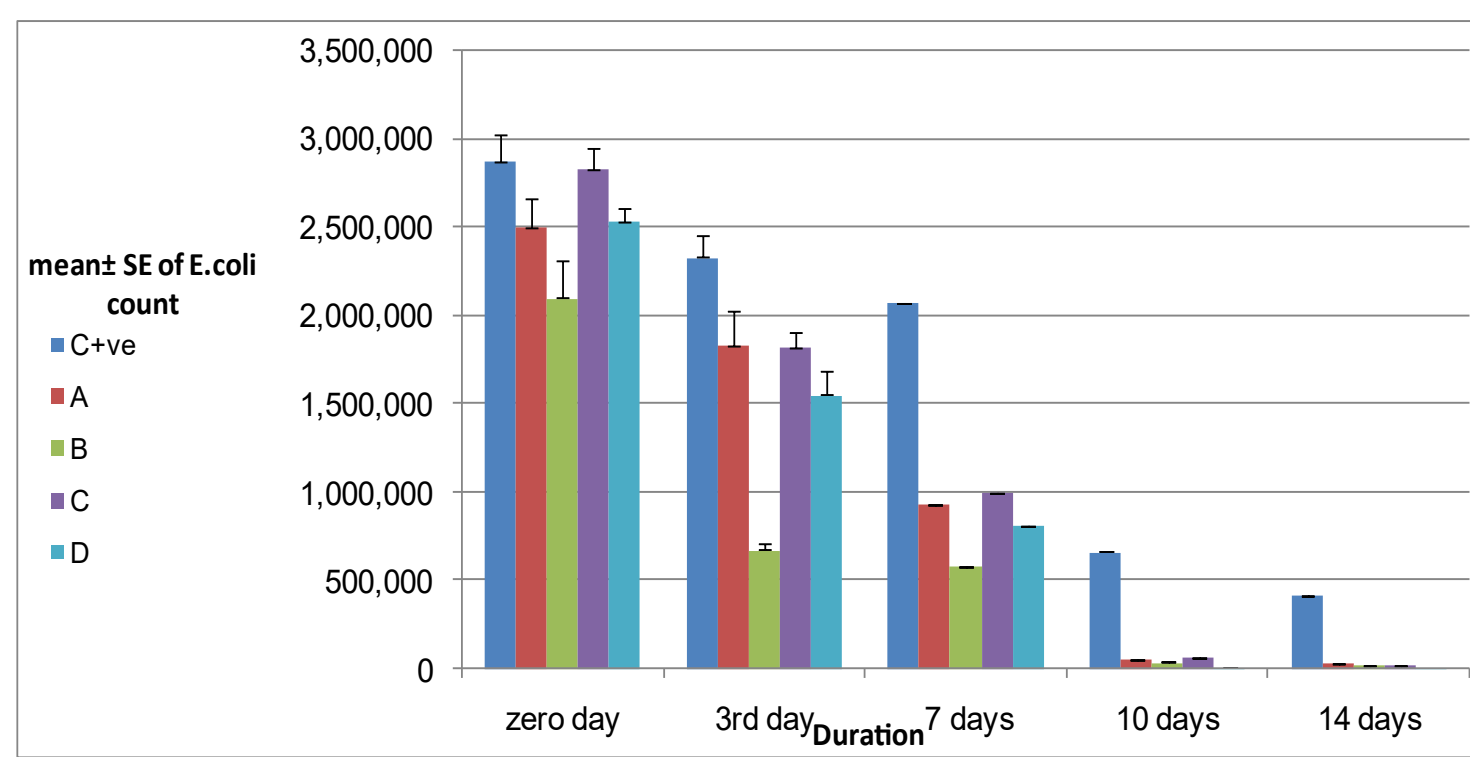

Figure 1: Antimicrobial activity of pomegranate Fruit peels extract and Moringa oleifera leaves extract on E.coli count inoculated in yoghurt during refrigerated storage.

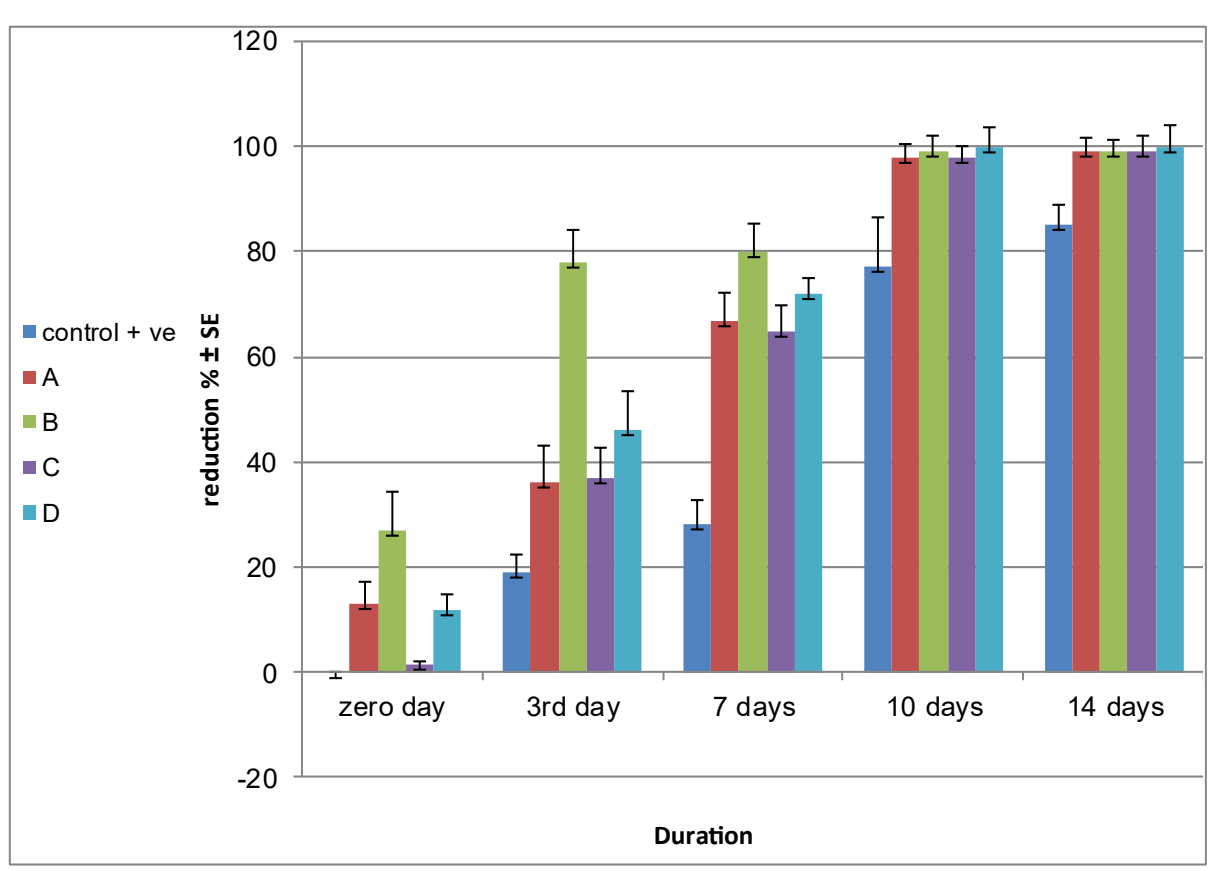

Figure 2: Reduction $\% \pm \mathrm{SE}$ of $E$. coli inoculated into yoghurt during storage.

The scores for body and texture were not affected by the treatments on the beginning of storage, where, all treatments and control yoghurt had a lot of $75 \%(30 / 40)$ of total score through storage period and were accepted. El-Batawy, et al. [23] found yoghurt with $1 \%$ pomegranate peel powder had higher flavor score and sensory quality of yoghurt product compared with yoghurt samples supplemented with $2 \%$ pomegranate peel powder. El-Gammal RE, et al. [24] found that the scores for sensory evaluation of the samples were showed for appearance and flavor, the addition of Moringa oleifera extract at mentioned concentrations had no unfavorable effect on appearance and flavor of the yoghurt samples. Akajiaku LO, et al. [25] evaluated the quality of yoghurt enriched with Moringa oleifera leaves powder at different ratios $(0.5,1,1.5,2.0 \mathrm{~g})$ incorporated in the production of yoghurt. Results showed that the control was the best choice and gained highest mean score for all sensory attributes (color, taste, flavor, mouth-feel and general acceptability). Sample with $1 \mathrm{~g}$ ratio had the highest score for general acceptability when compared to other treatments and was second in overall preference. Al-Ahwal RIH, et al. [26] examined flavored yoghurt like products with Moringa oleifera at concentration of $2,4,6,8$ and $10 \%(\mathrm{w} / \mathrm{w})$ compared with control. 
Results revealed that 2 and $4 \%$ of the extract did not affect any of the sensory, texture and chemical parameters compared to control but it increased the antioxidant capacity by up to $40 \%$.

It could be concluded that Moringa oleifera could be used at 2 and $4 \%$ in the preparation of made yoghurt-like, which resulted in an increase in the health benefits and the acceptability sensory attributes.

All treatments and control yoghurt were acceptable for all judgment members either it was fresh or stored. This means that the pomegranate peel extract and Moringa oleifera leaves extract can be used in making of yoghurt to enhance its antibacterial, functional and healthy properties. These results were in agreement with those reported by Madukwe EU, et al. [27].

Pomegranate peels are characterized by an interior network of membranes comprising almost $26-30 \%$ of total fruit weight and are characterized by substantial amounts of phenolic compounds, including flavonoids (anthocyanins, catechins and other complex flavonoids) and hydrolyzable tannins (punicalin, pedunculagin, punicalagin, gallic and ellagic acid). These compounds are concentrated in pomegranate peel and juice, which account for $92 \%$ of the antioxidant activity associated with the fruit [28].

Results recorded in tables 2 and 3 and figures 1 and 2 showed that pomegranate fruit peels $1 \%$ and $2 \%$ extracts reduced E. coli count that inoculated in yoghurt during storage to $2.97 \times 10^{4} \pm 0.2 \times 10^{4}$ and $1.83 \times 10^{4} \pm 0.08 \times 10^{4}$ with reduction percent reached to $98.96 \%$ and $99.36 \%$ after 14 days storage, respectively, pomegranate fruit peels extract $2 \%$ had more antimicrobial activity than $1 \%$ extract. Hussein ZG, et al. [29] found that the pomegranate peel extract showed antibacterial activity against E.coli ATCC 25922 which was exhibited by the formation of 14 and $25 \mathrm{~mm}$ zone of inhibition when 62.5 and $250 \mu \mathrm{g} / \mathrm{ml}$ of the extract was tested respectively by the agar diffusion method. Nuamsetti T, et al. [16] found all different extracts of pomegranate fruit peels had antibacterial effect against E.coli and they also mentioned that pomegranate extract contained high levels of phenolics and which had exhibited antibacterial activity against the bacteria tested. Pagliarulo C, et al. [30] extracted pomegranate arils and peel by-products in $50 \%(\mathrm{v} / \mathrm{v})$ aqueous ethanol, in order to test antimicrobial activity against clinically isolated human pathogenic microorganisms their results showed that both pomegranate aril and peel extracts have an effective antimicrobial activity, as evidenced by the inhibitory effect on the bacterial growth of two important human pathogens, including Staphylococcus aureus and Escherichia coli, which are often involved in food-borne illness.

Malviya S, et al. [31] tested the antibacterial activity of pomegranate peel extracts against four bacterial strains, Staphylococcus aureus, Enterobacter aerogenes, Salmonella typhi and Klebsiella pneumoniae and the extracts demonstrated remarkable antibacterial activities against all the tested bacterial strains, they also reported that $P$. granatum contains large amount of tannins (25\%) and antibacterial activity may be indicative of the presence of secondary metabolites. Abd El-Aziz ME, et al. [19] studied using of 1\%, 0.75\%, 0.5\% and $0.25 \%$ of Pomegranate fruit peels on yoghurt processing and the data indicates that $1 \%$ of extract was appropriate for the viability of Lactic acid bacteria which was above $30 \times 10^{6} \mathrm{CFU} / \mathrm{ml}$. In addition, was acceptable for the chemical, microbiological and organoleptical properties of the resultant yoghurt. And all the extracts had inhibitory activity against all bacteria tested, S.aureus and E.coli. The inhibitory effects were augmented with increase in extract concentrations. The reason of the inhibition might be due to the high content of phytochemical and phenolic compounds in pomegranate peels hot water extract.
Khan JA, et al. [32] stated that the antimicrobial activity of pomegranate peel against E. coli could most probably be related to its oxidizing property since the active compositions of pomegranate peel (phenolic acids) act as oxidizing antimicrobial agents, while Fischer UA, et al. [33] mentioned that pomegranates have the highest concentration of punicalagin among the most commonly consumed fruits. Studies have shown that punicalagin has antioxidant, antifungal and antibacterial properties.

Results recorded in tables 2 and 3 and figures 1 and 2 showed that Moringa oleifera leaves $1 \%$ and $2 \%$ extracts reduced E. coli count which was inoculated in yoghurt during storage to $2.20 \times 10^{4} \pm 0.23$ $\times 10^{4}$ and $2 \times 10^{2} \pm 0.28 \times 10^{2}$ with reduction percent reach to $99.2 \%$ and $99.99 \%$ after 14 days storage, respectively. The results showed that $2 \%$ Moringa oleifera leaves extract had the highest antibacterial effect against the tested bacteria. Bukar A, et al. [34] investigated the chloroform and ethanolic extracts of the seeds and leaves of Moringa oleifera for antimicrobial activity against some selected food-borne microorganisms. They found that the ethanolic extract of Moringa oleifera leaves exhibited broad spectrum activity against the test organisms like Escherichia coli, Pseudomonas aeruginosa, Staphylococcus aureus and Enterobacter aerogenes. Lar PM, et al. [35] studied the antibacterial activity of aqueous and ethanolic extracts of Moringa oleifera seed against some Gram negative bacteria (Escherichia coli, Shigella flexneri and Salmonella typhi). The concentration of the extracts used was between $50 \mathrm{mg} / \mathrm{ml}$ and $400 \mathrm{mg} / \mathrm{ml}$. The results evaluated by zones of inhibition showed that the ethanolic extract at $400 \mathrm{mg} / \mathrm{ml}, 200 \mathrm{mg} / \mathrm{ml}$ and $100 \mathrm{mg} / \mathrm{ml}$ were inhibitory to Escherichia coli, while Badmos AHA, et al. [36] assayed the bacterial status and nutritional-cum sensory properties of West African Soft Cheese treated with 3 levels $(1 \%, 2 \% \& 3 \%)$ of ethanol and ether extracts of Moringa oleifera leaves. The results indicated that $2 \%$ and $3 \%$ Moringa oleifera leaves ethanolic extracts had the highest inhibitory potential against bacteria population It can thus be concluded that the use of ethanol extract of Moringa oleifera leaves as a Cheese preservative leads to improved microbial stability and nutritional quality, as well as higher sensory acceptability. El-Sayed SM, et al. [37] added Moringa oleifera to Labneh at concentration $1 \mathrm{mg} / \mathrm{ml}, 1.5 \mathrm{mg} / \mathrm{ml}$ and $2 \mathrm{mg} / \mathrm{ml}$ and the results showed that increasing the concentration of Moringa oleifera increase the count of Lactic Acid Bacteria while Hassan FAM, et al. [38] found that the addition of Moringa oleifera leaves powder during yoghurt manufacture at ratio $(0.5,1,1.5$ and $2 \%)$ did not alter the acidification profile of yoghurt this reflects that the starter was not affected by the fortification and Shokery SE, et al. [39] mentioned that Moringa oleifera extract had a little stimulated effect on the growth of starter cultures in yoghurt, but not significant. Mohamed FA, et al. [40] studied the effect of Moringa oleifera leaves extracts with different solvents and water at varied concentrations on the growth of probiotics bacteria. The results showed that increasing the concentration of different extracts from control to $4 \mathrm{mg} \mathrm{mL}^{-1}$ medium lead to raise the probiotic bacterial growth. Also, it could be recognized that all studied probiotic bacteria significantly propagated well when using ethanol in the extraction compared with the aqueous extract. Kasolo JN, et al. [41] reported that Moringa oleifera leaves contain alkaloids, nitrogen containing naturally occurring compound that has the ability to intercalate with DNA of microorganisms which could be responsible for the much acclaimed medicinal values and Onyekaba TC, et al. [42] mentioned that generally, mechanism of action by the phytochemical constituents of Moringa oleifera is the reason for antibacterial activity thereby causing bacterial enzyme inhibition such as the sortase inhibitory effect, DNA replication, bacterial toxin action and causing the lysis of bacterial cells. It had been suggested that pterygospermin 
acts by the inhibition of the transaminase enzyme and through cell membrane perturbations. El-Gammal RE, et al. [24] stated that the aqueous extract of Moringa oleifera contained a bioactive compounds namely tannins, flavonoids, saponin, alkaloids and terpenes, and therefore the addition of Moringa oleifera extract to yoghurt enhances the nutritional value of the resultant yoghurt and had no unfavorable effect on appearance and flavor of the yoghurt samples. They also studied the antimicrobial activity of different concentration $(0.1,0.2,0.3$ and $0.4 \%)$ of water-based Moringa oleifera extract against some microorganisms and they found that the extract exhibited antibacterial activity against Gram positive bacteria (S. aureus, E. faecalis and B. cereus), in contrast to Gram negative bacteria (E.coli and S. Typhimurium) were more resistance to extract of Moringa oleifera.

\section{References}

1. Lahucky R, Nuernberg K, Kovac L, Bucko O, Nuernberg G (2010) Assessment of the Antioxidant Potential of Selected Plant Extracts in vitro and in vivo Experiments on Pork. Meat Sci 85: 779-784.

2. Carocho M, Morales P, Ferreira ICFR (2015) Natural Food Additives: Quo vadis? Trends Food Sci Technol 45: 284-295.

3. Heber D (2011) Pomegranate Ellagitannins. In: Benzie IFF, WachtelGalor S (eds) Herbal Medicine Biomolecular and Clinical Aspects. $2^{\text {nd }}$ edition, CRC Press, USA 201-203.

4. Basu A, Penugonda K (2009) Pomegranate Juice: A Heart-Healthy Fruit Juice. Nutr Rev 67: 49-56.

5. Fischer UA, Jaksch AV, Carle R, Kammerer DR (2013) Influence of Origin Source, Different Fruit Tissue and Juice Extraction Methods on Anthocyanin, Phenolic Acid, Hydrolysable Tannin and Isolariciresinol Contents of Pomegranate (Punica granatum L.) Fruits and Juices. Europ Food Res Technol 237: 209-221.

6. El-Din HMF, Sherif SM, El-Messery TM (2014) Role of the Functional Food (Pomegranate-Yoghurt) as Hepatoprotective Effect on Liver Injured Rats. Int J Curr Microbiol App Sci 3: 185-196.

7. Moyo B, Masika PJ, Hugo A, Muchenje V (2011) Nutritional Characterization of Moringa (Moringa oleifera Lam.) Leaves. Afr J Biotechnol 10: 12925-12933.

8. Mishra SP, Singh P, Singh S (2012) Processing of Moringa oleifera Leaves for Human Consumption. Bulletin Environ Pharmacol Life Sci 2: 28-31.

9. Abalaka ME, Daniyan SY, Oyeleke SB, Adeyemo SO (2012) The Antibacterial Evaluation of Moringa oleifera Leaves Extracts On Selected Bacterial Pathogens. J Microbiol Res 1: 1-4.

10. Hekmat S, Morgan K, Soltani M, Gough R (2015) Sensory Evaluation of Locally-Grown Fruit Purees and Inulin Fiber on Probiotic Yogurt in Mwanza, Tanzania and the Microbial Analysis of Probiotic Yogurt Fortified with Moringa oleifera. J Health Popul Nutr 33: 60-67.

11. Dachana KB, Rajiv J, Indrani D, Prakash J (2010) Effect Of Dried Moringa (Moringa oleifera Lam.) Leaves on Rheological, Microstructural, Nutritional, Textural and Organoleptic Characteristics of Cookies. J Food Qual 33: 660-677.

12. Ashraf R, Shah NP (2011) Selective and Differential Enumerations of Lactobacillus delbrueckii subsp. bulgaricus, Streptococcus thermophilus, Lactobacillus casei and Bifidobacterium spp. in Yoghurt-A Review. Int J Food Microbiol 149: 194-208.

13. Corrieu G, Béal C (2016) Yogurt: The Product and Its Manufacture. Encyclopedia Food Health 5: 617-624.
14. Salvador A, Fiszman SM (2004) Textural and Sensory Characteristics of Whole and Skimmed Flavored Set-Type Yoghurt During Long Storage. J Dairy Sci 87: 4033-4041.

15. Elbarbary HA, Saad MA (2018) Traditional and probiotic yoghurts in a comparative study. Acad J Agric Res 6: 55-59.

16. Nuamsetti T, Dechayuenyong $P$, Tantipaibulvut $S$ (2012) Antibacterial Activity of Pomegranate Fruit Peels and Arils. Scienceasia 38: 319322.

17. Majali IS, Oran SA, khleifat KMA, Qaralleh H, Rayyan WA, et al. (2015) Assessment of the Antibacterial Effects of Moringa peregrine Extracts. African J Microbiol Res 9: 2410-2414.

18. Abdallah EM (2016) Antibacterial Properties of Leaves Extracts of Moringa oleifera Lam. Growing in Sudan. J Adv Med Pharm Sci 5: 1-5.

19. Abd El-Aziz ME, El-Gammal RE, Abo-srea MM, Faten I Youssf (2013) Antioxidant and Antimicrobial Activity of Pomegranate (Punica granatum L.) Fruit Peels Extract on Some Chemical, Microbiological and Organoleptical Properties of Yoghurt During Storage. Mansoura J Food and Dairy Sci 4: 387-400.

20. Fatma AM Hassan, Hala M Bayoumi, Mona AM Abd Elgawad, Enab AK, Youssef YB (2016) Utilization of Moringa oleifera Leaves Powder in Production of Yoghurt. Int J Dairy Sci 11: 69-74.

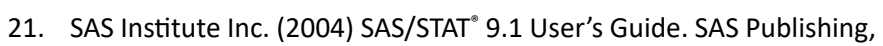
Cary NC, USA.

22. Marwa M El-Said, Haggag HF, Hala M Fakhr El-Din, Gad AS, Azza $M$ Farahat (2014) Antioxidant Activities and Physical Properties of Stirred Yoghurt Fortified with Pomegranate Peel Extracts. Annals Agri Sci 59: 207-212.

23. El-Batawy OI, Ashoush IS, Nayra Sh Mehanna (2014) Impact of Mango and Pomegranate Peels Supplementation on Quality Characteristics of Yoghurt with or Without Whey Powder. World J Dairy Food Sci 9: 57-65.

24. El-Gammal RE, Abdel-Aziz ME, Darwish MS (2017) Utilization of Aqueous Extract of Moringa oleifera for Production of Functional Yoghurt. Mansoura J Food Dairy Sci 8: 45-53.

25. Akajiaku LO, Kabuo NO, Omeire GC, Odimegwu EN, Ogbonna VG (2018) Production and Evaluation of Moringa oleifera Leaves Powder Enriched Yogurt. Nutr Food Toxicol 2: 459-466.

26. Al-Ahwal RIH, Saleh AE, Moussa MAM (2017) The Importance of Using Moringa Oleifera Extract on the Quality and Nutritive Value of Yoghurt. Mansoura J Food and Dairy Sci 8: 237-241.

27. Madukwe EU, Ezeugwu JO, Eme PE (2013) Nutrient Composition and Sensory Evaluation of Dry Moringa oleifera Aqueous Extract. Int J Basic Applied Sci 13: 100-102.

28. Zahin M, Aqil F, Ahmad I (2010) Broad Spectrum Antimutagenic Activity of Antioxidant Active Fraction of Punica granatum L. Peel Extracts. Mutat Res 703: 99-107.

29. Hussein ZG, Ali NM (2013) The Effect of Pomegranate Peel Extract and Vitamin $C$ in Comparison With Gemifloxacin On Inhibiting Adhesion of Escherichia coli to uroepithelial cells. Zanco J Med Sci 17: 429-434.

30. Pagliarulo C, Vito VD, Picariello G, Colicchio R, Pastore G, et al. (2015) Inhibitory Effect of Pomegranate (Punica granatum L.) Polyphenol Extracts on the Bacterial Growth and Survival of Clinical Isolates of Pathogenic Staphylococcus aureus and Escherichia coli. Food Chem 190: 824-831. 
31. Malviya S, Arvind, Jha A, Hettiarachchy N (2014) Antioxidant and Antibacterial Potential of Pomegranate Peel Extracts. J Food Sci Technol 51: 4132-4137.

32. Khan JA, Hanee S (2011) Antibacterial Properties of Punica granatum Peels. Int J Appl Biol Pharm 2: 23-27.

33. Fischer UA, Carle R, Kammerer DR (2011) Identification and Quantification of Phenolic Compounds from Pomegranate (Punica granatum L.) Peel, Mesocarp, Aril and Differently Produced Juices by HPLC-DAD-ESI/MS(n). Food Chem 127: 807-821.

34. Bukar A, Uba A, Oyeyi TI (2010) Antimicrobial Profile of Moringa oleifera Lam. Extracts Against Some Food-borne Microorganisms. Bayero J Pure Appl Sci 3: 43-48.

35. Lar PM, Ojile EE, Dashe E, 'Oluoma JN (2011) Antibacterial Activity of Moringa oleifera Seed Extracts on Some Gram Negative Bacterial Isolates. African J Natural Sci 14: 57-62.

36. Badmos AHA, Ahmed EAM, Ajiboye DJ (2014) The Effect of Crude Leaves Extracts of Moringa oleifera on the Bacterial, Nutritional and Sensory Properties of West African Soft Cheese. Wayamba J Anim Sci 6: 939-946.
37. El-Sayed SM, El-Sayed HS, Salama HH, Abo El-Nor SAH (2017) Improving the Nutritional Value and Extending Shelf Life of Labneh by Adding Moringa oleifera Oil. Int J Dairy Sci 12: 81-92.

38. Hassan FAM, Bayoumi HM, Abd El-Gawad, Enab AK, Youssef YB (2016) Utilization of Moringa oleifera Leaves Powder in Production of Yoghurt. Int J Dairy Sci 11: 69-74.

39. Shokery SE, Mohamed GE, Asmaa H Yossef, Reda IM (2017) Effect of Green Tea and Moringa Leave Extracts Fortification on the Physicochemical, Rheological, Sensory and Antioxidant Properties of Set-Type Yoghurt. J Adv Dairy Res 5: 179.

40. Mohamed FA, Salama HH, Samah M El-Sayed, Hoda S El-Sayed, Zahran HA (2018) Utilization of Natural Antimicrobial and Antioxidant of Moringa oleifera Leaves Extract in Manufacture of Cream Cheese. J Biol Sci 18: 92-106.

41. Kasolo JN, Gabriel S, Bimenya LO, Joseph O, Ogwal Okeng JW (2010) Phytochemicals and Uses of Moringa oleifera Leaves in Ugandan Rural Communities. J Med Plants Res 4: 753-757.

42. Onyekaba TC, Chinedu OG, Fred AC (2013) Phytochemical Screening and Investigations of Antibacterial Activities of various fractions of the Ethanol Leaves Extract of Moringa Oleifera LAM (Moringaceae). J Pharm Chem Biol Sci 3: 962-973. 